\title{
Innovation studies in Latin America: a bibliometric analysis
}

\author{
Jorge Tello-Gamarra ${ }^{1}$,Ricardo Machado Leo ${ }^{2 *}$, Ariane Mello Silva Avila², Jonatas Wendland ${ }^{3}$
}

\begin{abstract}
The article's objective is to present a quantitative overview of innovation studies developed by Latin American authors. We adopted the bibliometric method to build the study, with data originated from the Scopus and Web of Science databases, covering 30 years (1987-2016). From this data analysis, we found out that innovation studies in Latin America, for long period, did not present a significant volume. However, this scenario has undergone changes, such as: (1) the growth in the volume of publications of the countries; (2) the relevant collaboration between Latin American countries and the United States, Spain, and the United Kingdom; (3) and relevant presence of Brazilian authors and universities as the most productive in the region. Despite these changes, Latin America still falls behind the reference countries in the area, accounting for $2.75 \%$ of the worldwide bibliographic production on innovation in the databases analyzed.
\end{abstract}

Keywords: innovation studies; bibliometric analysis; Latin-America; Scopus; Web of science

Submitted: May 29 2018 / Approved: November $6^{\text {th }}, 2018$

\section{Introduction}

In academia, the term innovation emerged with the pioneering work of Joseph Schumpeter entitled "The Theory of Economic Development". After this theoretical contribution, for a long time, little interest was devoted to innovation studies and works on the field was sporadic (Fagerberg et al., 2011). Nevertheless, after the 1950s decade, due to the theoretical and empirical contributions of several scholars (Solow, 1957; Freeman, 1974; Rosenberg, 1976; Nelson \& Winter, 1982; Pavitt, 1984; Dosi, 1982; Teece, 1986; Lundvall, 1992; Christensen, 1997; etc.), such scenario started to change.

Currently, innovation studies are a prominent research field (Fagerberg \& Verspagen, 2009) driven by the increase in the number of business schools and researchers interested in innovation and innovation-related topics, in addition to the stimuli caused by the growing demand for a greater comprehension of the nature of innovation processes for policy and management purposes (Martin, 2016).

Originally named as science and technology studies (Godin, 2014), innovation is a multidisciplinary research field formed by disciplines such as economics, management, political science, organizational science, technology, and innovation, which gather to generate knowledge for the economic development and growth (Martín, 2016; Solow, 1957; Schumpeter, 1911). Therefore, with the aim to advance towards the consolidation of this research field, a set of studies has emerged to characterize this area of knowledge and to point different perspectives and challenges. In the world literature as a whole, this information is available due to different bibliometric studies (Fagerberg \& Verspagens, 2009; Fagerberg et al., 2012; Sun \& Grimes, 2016).

In Latin America, innovation studies have been carried out with some lag when compared to the United States and Europe and, although in the 1970s decade some authors (Sábato, 1971; Sagasti, 1973; Perez, 1986; Katz, 1984) started to conduct initial studies on innovation, the research area only gained momentum at the beginning of the $21^{\text {st }}$ century. Besides the lagging, except of the studies of Ketelhöln and Ogliastri (2013), Lazzarotti, Dalfovo and Hoffmann (2011), Olavarrieta and Villena (2014) and Zawislak, Tello-Gamarra, Fracasso and Castellanos (2017), a lack of research can be noticed on the identification and characterization of innovation studies in Latin America.

With the aim to assist literature fulfilling this gap, this article's objective is to analyze innovation studies in Latin America, seeking to identify a set of quantitative information from these studies. We adopted the bibliometric method to build the study. The results provide an overview of Latin-American scientific production on innovation studies and, consequently, it provides decision-making bases for innovation policies, in light of the recognition of innovation as an essential condition for the economic progress of regions (Freeman, 1974). Such information enabled the identification of the academic production volume during the thirty years analyzed, the countries that collaborate outside the region and the most productive universities. Also, we analyzed the most frequently published journals, types of documents, most productive and cited authors and the most used languages for publication.

Thus, the structure of this article is divided in 4 more sections. Section 2 presents the literature review, which aims to discuss the development of innovation around the world and to present the most prominent Latin-American studies. Afterward, in Section 3, we present the method applied and we explain the steps followed to obtain the results. Finally, in Section 4, we present the quantitative results found and, finally, we discuss the findings in Section 5, where we also present the limitations and the practical implications derived from this study.

(1) School of Chemistry and Food, Federal University of Rio Grande (FURG), Brazil

(2) School of Management, Federal University of Rio Grande do Sul (UFRGS), Brazil.

(3) Institute of Economic, Administrative and Accounting Sciences, Federal University of Rio Grande (FURG), Brazil.

${ }^{*}$ Corresponding author: ricardomachado_3@hotmail.com

ISSN: 0718-2724. (http://jotmi.org)

Journal of Technology Management \& Innovation (c) Universidad Alberto Hurtado, Facultad de Economía y Negocios. 


\section{Literature Review}

The first innovation definition was proposed by Joseph Schumpeter (1911) in his work "The Theory of Economic Development," where the author associated innovation to the economic development and defined it as a new combining way of productive resources. This work, initially launched in German and later translated into English, established specific types of innovation, such as the introduction of new products, new production methods, the exploration of new markets, new supplying sources and new methods of industrial organization. Also, the author pointed that the relationship between innovation and economic development was due to breaks in an economic equilibrium, where the ruptures were waves that came to destabilize the existing equilibrium. Moving forward in his studies, Schumpeter (1942), in his book "Capitalism, Socialism, and Democracy," coined the term "creative destruction". This term is based on the fact that companies introduce new goods and production processes in order to make existing technologies obsolete, and therefore, take over the market of the companies that were not capable of introducing new goods and production processes. In this sense, one of the foundations that compose capitalism is the destruction of the old for the emergence of the new, the innovation.

Schumpeter's studies catalyzed new contributions to the theme. Some of these contributions came from Christopher Freeman, who followed the Schumpeterian assumptions about the role of innovation in economic and social change. In his book "The Economics of Industrial Innovation" published in 1974, Freeman sought to reveal the characteristics of the technological strategies adopted by the companies. Also, Freeman's contribution is relevant because it highlights the need to standardize innovation indicators and stimulate scientific research. The emphasis on the need for uniformization comes from works that sought to standardize innovation indicators, such as the Frascati Manual and the Oslo Manual, collaborating to determine guidelines and policies in the measurement of innovation internationally (Lazzarotti, Dalfovo \& Hoffmann, 2011). On the other hand, the stimulus to the development of scientific research is due to Freeman's recognized characteristic as a social science entrepreneur (Fagerberg et al., 2011), since he funded the unit of innovation studies SPRU (Science Policy Research Unit), in the University of Sussex, in 1965, which served as a model for several innovation study centers worldwide. This initiative attracted a vast number of researchers from several countries who saw in SPRU and Freeman the opportunity to develop research in this area.

In addition to Schumpeter and Freeman, several other authors had innovation as the central issue in their work. Robert Solow (1957) suggests that economic growth is due to technology improvement, contrary to the perspective of capital accumulation. Nathan Rosenberg (1976) focused his research on technological, institutional, and economic evolution, which allowed the development of more systematic analyses of innovation. Nelson and Winter evidenced in their work "An Evolutionary Theory of Economic Change" published in 1982, that companies are inserted in routines, creating trajectories in which they cumulatively develop knowledge on how to perform their activities. These routines hold them in certain trajectories making it difficult to exit, explaining, in the authors' view, why some firms are capable of innovate and why others are not. At the same level of relevance, Edith Penrose, in her work "The Theory of the Growth of the Firm" published in 1959, emphasizes that innovation depend on the new viable resources and capabilities whose operation adds new value to the existing circular flow of income, creating new profits and incomes.

Furthermore, Giovanni Dosi (1982), following the precepts of Nelson and Winter (1982), in his work "Technological Paradigms and Technological Trajectories" suggests that there are "technological paradigms" which are structured, standardized, and cumulative set of technological knowledge, innovative opportunities, and productive patterns. Furthermore, David Teece (1986) sought to explain in his work "Profiting from Technological Innovation" why some firms, although innovative, frequently fail to obtain a significant economic return. Keith Pavitt (1984) focused on the technical change strand, by creating sectorial taxonomies to classify industrial sectors, which are: supplier dominated, production intensive, and science-based. Clayton Christensen (1997) described how disruptive technologies undermine the competitive position of an established company by offering a cheaper and sufficiently good technological alternative for most of the clients. Lundvall (1992) states that innovation does not happen isolated, but in a holistic perspective, highlighting the role of interactions between organizations, the government, and universities, that is, the National Innovation System.

By focusing on Latin America, authors such as Jorge Sábato (1971), Francisco Sagasti (1973) Carlota Perez (1986) and Jorge Katz (1984) contributed with works in this area. Sábato (1971) relates the role of technology allied to science, developing a political, scientific, and technological model, the Sábato Triangle, where he tries to describe the three elements that are, historically, fundamental to the development of science and technology (government, the productive industry, and the scientific and technological infrastructure). The author argues that these elements must work in a coordinated way aiming to develop technological innovations in the national context. Sagasti (1973) examines the interrelationship between underdevelopment, science, and technology, claiming that the way science and technology developed in the twentieth century contributed to underdevelopment. On the other hand, Perez (1986) emphasizes that the notion of technological determinism not imply patterns of technological trajectories, since the technological paradigm offers ample space and, within this, also includes social forces, experiences, and institutional arrangements that shape, guide, select, and regulate the final course of the trajectories, possibly giving new potentials to these trajectories. Katz (1984) analyses the key factors affecting the acquisition of technological capabilities by industries in the least developed countries. He also identifies that much of the productivity increase comes from process optimization efforts, and the planning and organization of the production by adapting and improving existing technologies. Despite the importance of the contribution of these scholars, there is currently no bibliometric research on innovation studies in Latin America.

\section{Method}

This study is a bibliometric analysis, which has been used by many authors in a range of disciplines, including innovation. According to 
Bjork et al. (2014), bibliometric studies are useful when seeking generalized views of a research field and also to analyze the researchers. Thus, Sun and Grimes (2016) state that the bibliometric method is used to compare scientific activities to their different levels, including institutions, countries, and journals. In this sense, Boyack et al. (2002) argued that the bibliometric approach can be classified as follows: (1) a macro research plan that aims to define the structural units of science and their interrelations on a global scale; and (2) a micro research plan characterized by an attempt to establish knowledge within a specific disciplinary domain and, thus to inform its state of the art.

Therefore, this article is characterized as a micro bibliometric analysis, seeking to verify the publications of a specific field of knowledge, innovation, in the Latin American scope. To reach this result we sought to identify: (1) the evolution of the publications during the established period; (2) the number of publications of each Latin American country; (3) the number of citations of these works; (4) the authors; (5) the countries of residence of the authors who participated in these works; (6) the journals that published these works; (7) the affiliations of these authors; (8) the language of the published works; (9) the type of document; (10) the top countries publishing in the theme.

Moreover, we also sought to (11) the index resulting from the division of the citation number by the number of publications; and, finally, (12) the index resulting from the division of the number of citations by the number, in millions, of inhabitants in each country. These indices are relevant because they help to provide an analysis of the scientific production of a given area (Bonilla et al., 2015). Therefore, we chose the P/ Pop (number of publications divided by the number of the country's population) to verify how many articles are published by each inhabitant of the region and, also, the $\mathrm{C} / \mathrm{P}$ index (citations divided by the total number of publications) to verify the impact of these articles.

To obtain this information we used, in July 2017, two databases: Scopus and Web of Science. In the Scopus database, we searched the words "innovation", "technical change" and "technological change" in the three most used languages for scientific publication in Latin America: English (innovation, technical change, and technological change), Portuguese (inovação, mudança técnica and mudança tecnológica) and Spanish (innovación, cambio técnico and cambio tecnológico). The terms "technical change" and "technological change" were used as synonyms to the word "innovation" because literature also addresses them in such forms. Moreover, we observed that the terms "technical change" and "technological change" are more frequently used by researchers in the field of economics and the term "innovation" in business. Thus, we searched the terms on the three languages using the logic operator "or" so that the database would search for any of the words in the "title," "keywords," or in the abstract of the publications. Also, filters were added in order to limit the period of analysis, a field of study and countries of publication. For the analyzed period, we selected the publications of the last thirty years, that is, from 1987 to 2016, filtering for the research fields of "Business, Management and Accounting" and "Economics, Econometrics, and Finance." Regarding the countries, all Latin American countries were selected, according to OECD (2017).

In the Web of Science database, we also searched for the words "innovation," "inovação" and "innovación," using the logic operator "or" to search the terms in "Topics," the database equivalent to "Title," "Keywords" and "Abstract." From the result of this first stage, we used the same filters used in the Scopus database, however for the field of study we filtered the field for "Business," "Economics" and "Management." As the objective of this work is to identify studies on innovation in Latin America, we only considered the studies that had some affiliation to Latin American countries, not considering in this scope, the studies of innovation written by researchers born in the region but with affiliation to some foreign institution.

\section{Result}

\section{Evolution of research in Latin America}

During the last years, some countries in Latin-America experienced a representative economic growth, which has significantly contributed to the increase of research in these countries (Bonilla et al., 2015). Thus, when we analyze the number of published research on the theme innovation, this growth happened in a significant way after 2006, reaching in that year, the mark of 55 published documents in Scopus and 17 in the Web of Science database. A comparison, in 2005, Scopus presented 22 publications whereas Web of Science presented 8, that is, publications doubled between the two years in both databases. Moreover, publications in Latin America did not exceed 203 documents in the Scopus database, while in the Web of Science it reached 140 from 1987 to 2005.

Fig. 1 Total number of published documents on the innovation theme (1997 - 2016)

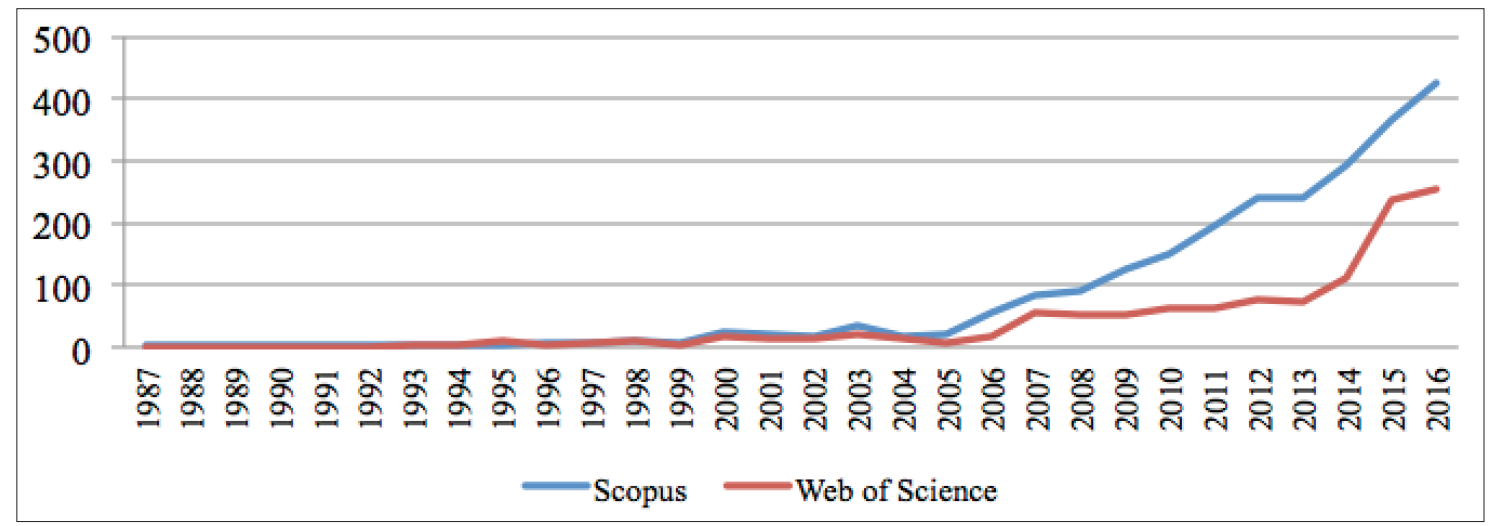

ISSN: 0718-2724. (http://jotmi.org)

Journal of Technology Management \& Innovation ( ) Universidad Alberto Hurtado, Facultad de Economía y Negocios. 
Figure 1 shows that after 2006, there is a growth in publications in both databases, reaching a mark in 2016 of 426 documents published in Scopus and 254 documents published in Web of Science. Furthermore, in 2016 alone, the sum of the articles published by both databases was more than the double of the articles published within the 1987-2005 period (Figure 1).

\section{Most productive Latin American countries}

After we verified that, in their entirety, studies are in full growth in the region, we found it necessary to analyze how much each Latin American country is publishing. Thus, in the Scopus database, Brazil leads innovation studies totaling 1,373 publications in the last 30 years with 5,471 citations. Other data regarding Brazil refers to the indicators of citation quantity divided by the total of publications $(\mathrm{C} / \mathrm{P})$ and the number of publications divided by country's population in millions of inhabitants (P/Pop). In these indicators, the country had a $\mathrm{C} / \mathrm{P}$ indicator of 3.98 and 6.60 of P/Pop.
Following Brazil, in the Scopus database, Mexico presents 317 publications, followed by Colombia with 233 and Chile with 201. Thus, in the face of the total number of papers published during the analyzed period, Mexico had 1,970 citations, Colombia 1,014, and Chile 1,492. Also, these countries also present $\mathrm{C} / \mathrm{P}$ indices of 6.21 and P/Pop of 2.48 for Mexico, 4.35 and 4.76 for Colombia and 7.42 and 11.17 for Chile. It is important to highlight that the $\mathrm{C} / \mathrm{P}$ index (citation per publication) presented by these countries is superior to that of the leader in Brazil. In other words, Mexico, Chile, and Colombia publish less in absolute numbers, though the articles published by these countries have more citations than those published by Brazilian authors. In addition to these countries, Uruguay also presents $\mathrm{C} / \mathrm{P}$ and $\mathrm{P} /$ Pop indices higher than the Brazilian ones: 5.11 and 12.86 respectively. Table 1 presents this information.

Table 1 Latin American countries with the higher number of publications on the theme innovation according to SCOPUS (1987-2016)

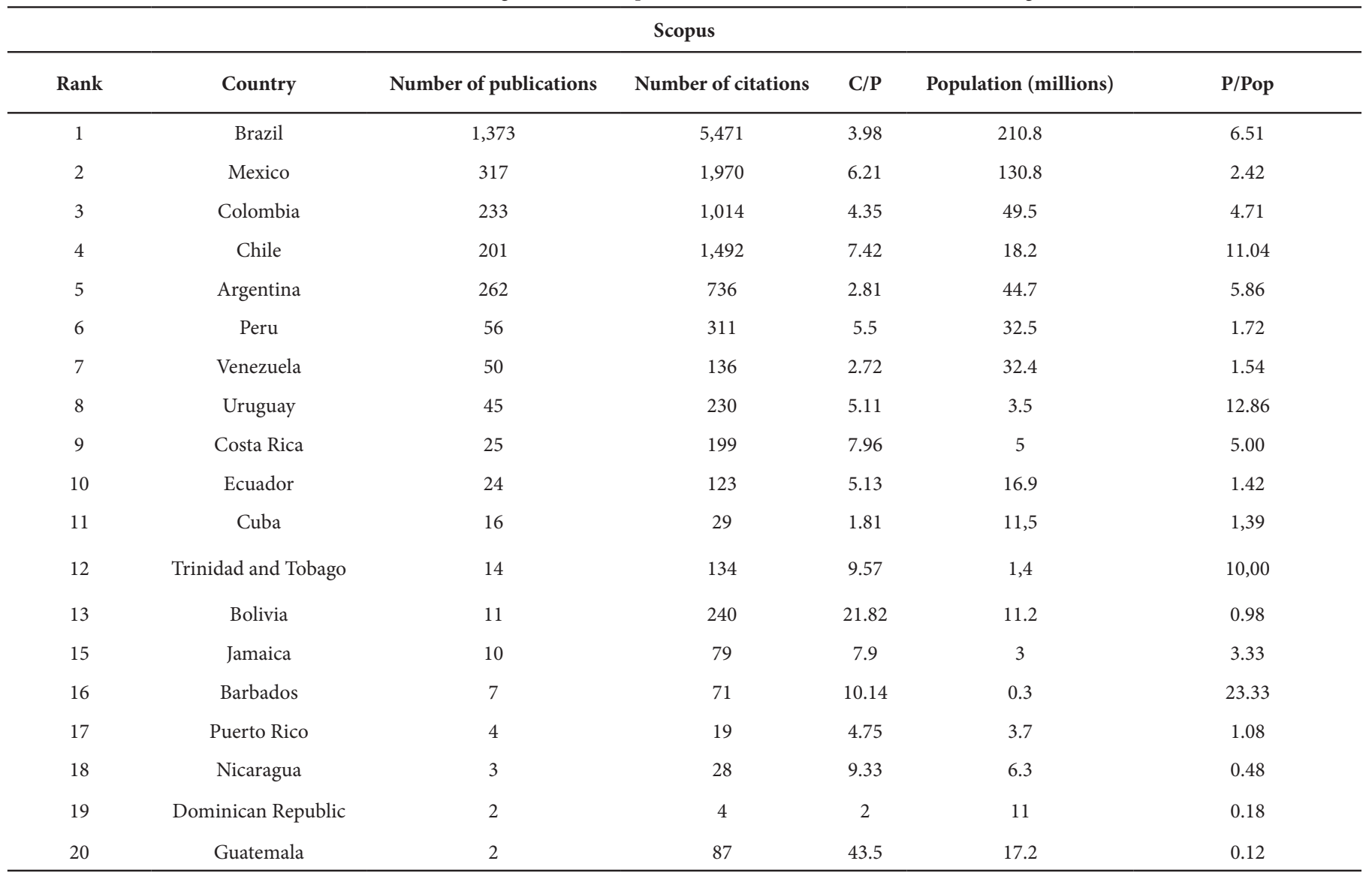

Note: C/P: citation per publication; P/Pop publication divided per country population; Population (millions) extracted from The World Bank (2018); Latin American countries according to the classification proposed by OECD (2017).

In the Web of Science database, Brazil also occupies the first position with a total of 550 publications, 2,889 citations, $5.25 \mathrm{C} / \mathrm{P}$ and 2.64 $\mathrm{P} / \mathrm{Pop}$ index, followed by Mexico with a total of 172 publications, a C/P index of 7.15 and a P/Pop index of 1.34, Colombia with 142 publications, 3.94 C/P and 2.90 P/Pop and Chile with 142 publications, 9.16 C/P and 7.89 P/Pop.
It should also be noted that the same phenomenon that occurred in the Scopus database was observed the Web of Science database, where countries ranked below surpassed the leader Brazil in the $\mathrm{C} / \mathrm{P}$ index, however with one caveat: in this index, considering Web of Science database, Colombia scored lower than Brazil. Table 2 presents this information. 
Table 2 Latin American countries with the higher number of publications on the theme innovation according to Web of Science (1987-2016)

\begin{tabular}{|c|c|c|c|c|c|c|}
\hline \multicolumn{7}{|c|}{ Web of Science } \\
\hline Rank & Country & Number of Publications & Number of Citations & $\mathbf{C} / \mathbf{P}$ & Population (millions) & P/Pop \\
\hline 1 & Brazil & 550 & 2,889 & 5.25 & 210.8 & 2.61 \\
\hline 2 & Mexico & 172 & 1,230 & 7.15 & 130.8 & 1.34 \\
\hline 3 & Colombia & 142 & 559 & 3.94 & 49.5 & 2.9 \\
\hline 4 & Chile & 142 & 1,301 & 9.16 & 18.2 & 7.89 \\
\hline 5 & Argentina & 86 & 729 & 8.48 & 44.7 & 1.95 \\
\hline 6 & Peru & 28 & 207 & 7.39 & 32.5 & 0.88 \\
\hline 7 & Uruguay & 24 & 102 & 4.25 & 3.5 & 6.86 \\
\hline 8 & Costa Rica & 24 & 76 & 3.17 & 5 & 4.8 \\
\hline 9 & Ecuador & 16 & 81 & 5.06 & 16.9 & 0.98 \\
\hline 10 & Venezuela & 14 & 40 & 2.86 & 32.4 & 0.44 \\
\hline 11 & Trinidad and Tobago & 9 & 85 & 9.44 & 1.4 & 6.43 \\
\hline 12 & Nicaragua & 8 & 21 & 2.63 & 6.3 & 1.31 \\
\hline 13 & Bolivia & 8 & 156 & 19.5 & 11.2 & 0.73 \\
\hline 14 & Cuba & 7 & 6 & 0.86 & 11.5 & 0.61 \\
\hline
\end{tabular}

Note: C/P: citation per publication; P/Pop publication divided per country population; Population (millions) extracted from The World Bank (2018); Latin American countries according to the classification proposed by OECD (2017).

Aiming to compare the countries with the higher number of publications on the innovation theme worldwide, we performed a new search in the two databases (Table 3). Globally, the countries that stand out publishing on the theme, in Scopus, are the United States with 16,933 publications, followed by the United Kingdom with 8,295 and China with 6,349 publications. On the other hand, in the Web of Science database, the United States stands out with 13,712 publications, followed by China with 9,264 and England with 5,786 publications. It is worth mentioning that Brazil was the only Latin American country figuring among the top twenty countries with the higher number of publications worldwide, presenting 1,373 publications in Scopus. Nevertheless, in the Web of Science database, Brazil is not in the top 20.

Table 3 Countries with the higher number of publications on innovation globally (1987-2016)

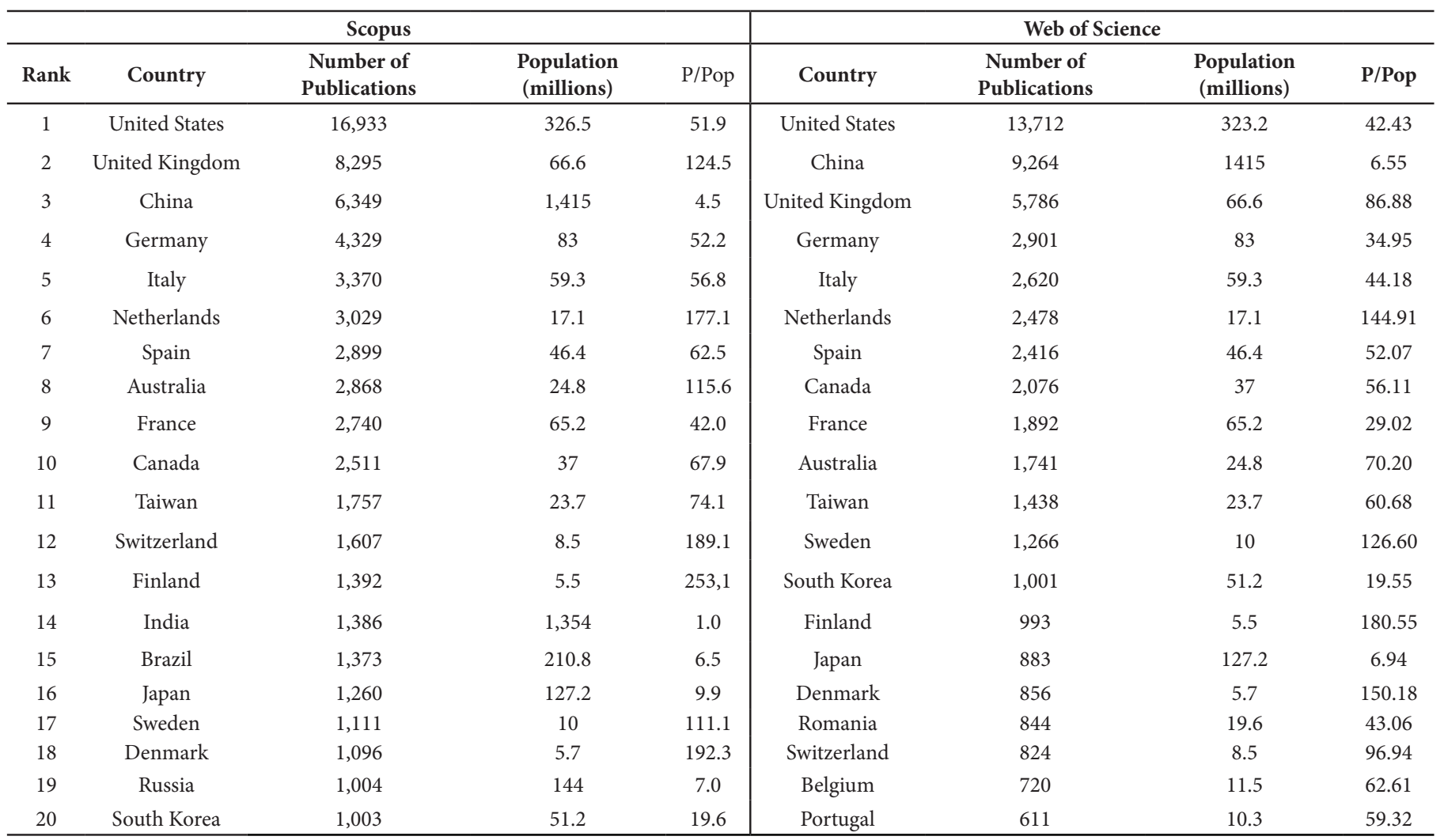

Note: P/Pop Publication divided per country population; Population (millions) extracted from The World Bank (2018). 


\section{Collaboration between countries}

By way of comparison, in Scopus, Latin America presents 3.3\% of the world publications, wherein the top one country, United States, alone presents $22.56 \%$ of the world's publications. In the Web of Science database, while Latin America presents $2.2 \%$ of the world's publications, the United States represents $25.4 \%$ of these publications.
Another point observed refers to the countries worldwide that are making partnerships with the region, that is, the non-Latin American countries with the highest co-authorships with Latin American authors (Table 4). According to the Scopus database, among the countries that stand out by the number of co-authorships are the United States, followed by Spain and, in third place, the United Kingdom. In the Web of Science database, the United States ranks first, followed by Spain and, in third place, England.

Table 4 Non-Latin American countries with the highest quantity of coauthorships with Latin American countries (1987-2016)

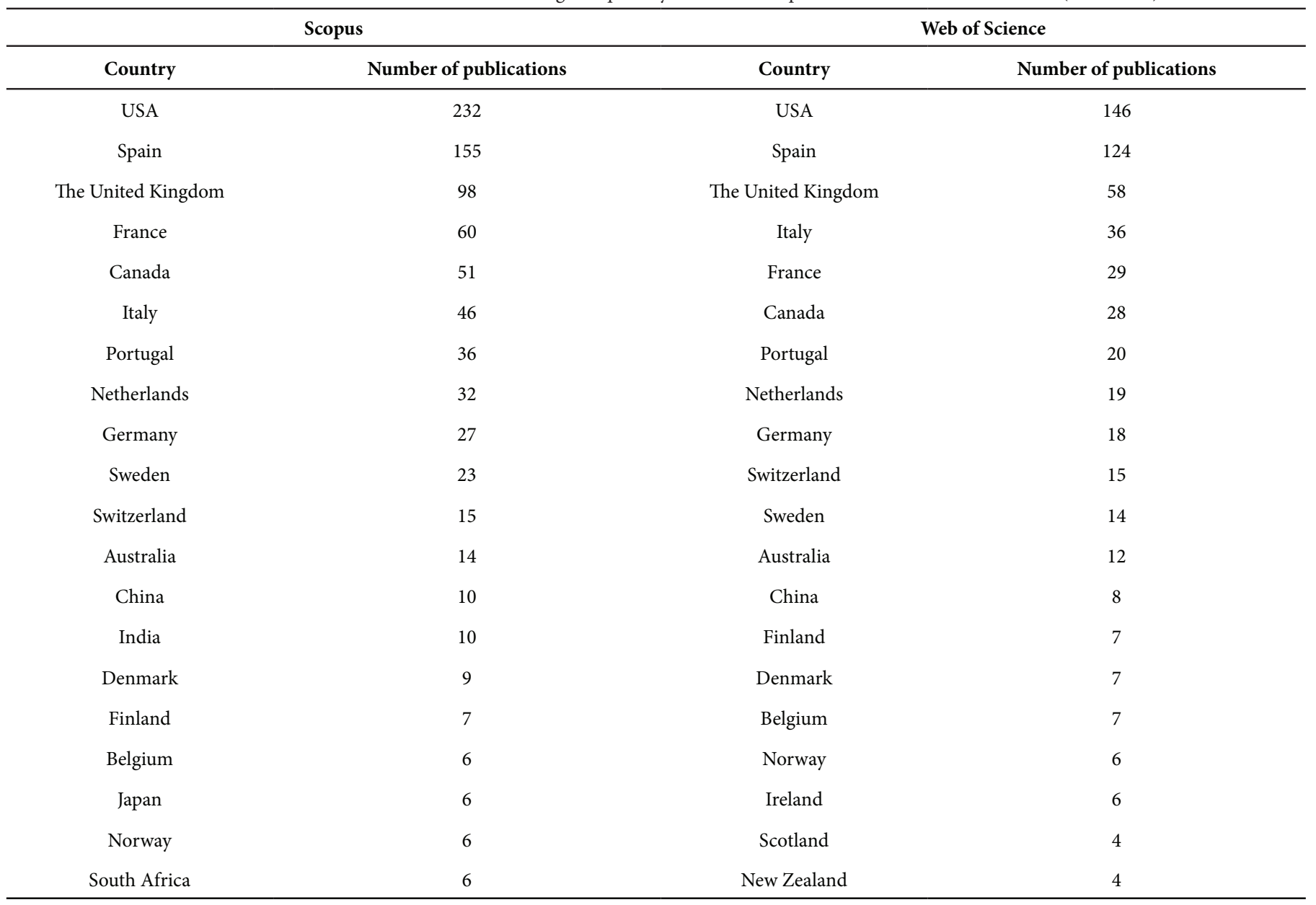

In both databases, we found that the USA, Spain, and the United Kingdom account for more than $57 \%$ of the co-authorship volume with Latin American countries. This data shows that, despite the relatively low share of Latin America on the worldwide publication volume, the region sets partnerships with leading countries in the subject.

\section{Most productive universities}

Regarding the institutions that generate such publications, in Scopus, Brazilian institutions stand out and occupy the four top positions with the University of São Paulo, Federal University of Rio de Janeiro, University of Campinas and Federal University of Rio Grande do Sul. The first non-Brazilian university is Tecnológico de Monterrey in the fifth position. It is worth highlighting that among the top twenty publishing universities, 13 are Brazilian universities (Figure 2). 
Fig 2 Main publishing institutions - Scopus (1987-2016)

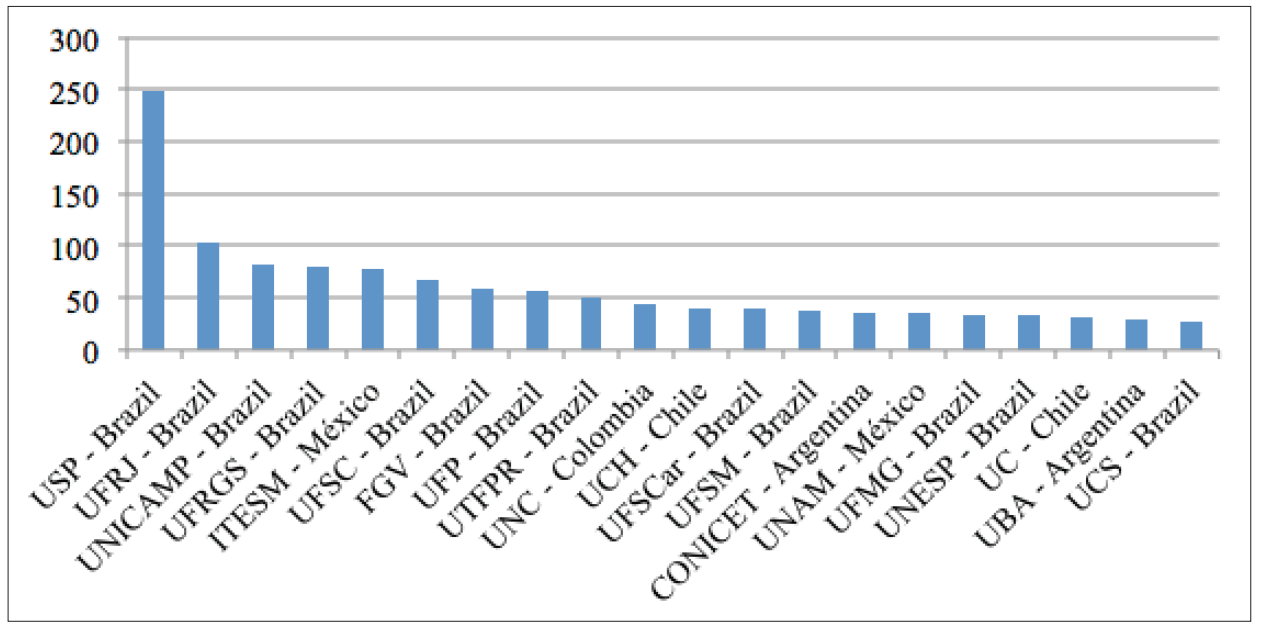

However, in the Web of Science database, Brazilian institutions stand out by occupying the two first positions with the University of São Paulo and the University of Campinas. The first non-Brazilian university is Tecnológico de Monterrey in the third position, followed by
Universidad de Chile in the fifth position. Unlike the Scopus database where there were 13 Brazilian universities among the top twenty, in the Web of Science database 10 Brazilian universities are found among the top twenty (Figure 3).

Fig 3 Main publishing institutions - Web of Science (1987-2016)

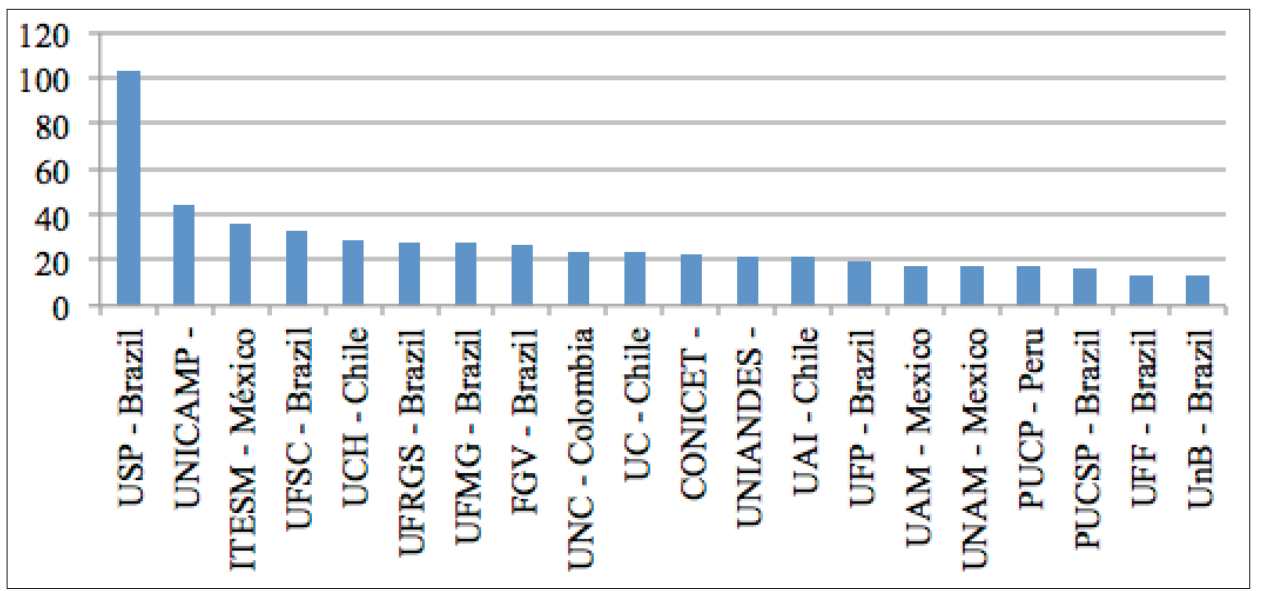

\section{Document Type and Journals}

Additionally, we analyzed the publishing vehicles (Table 5). In the 30 years analyzed, we found that the first publishing vehicle is the document type "Article" with 74\%, followed by "Conference Papers" with $13 \%$ and "Book chapter" with $8 \%$ of the works published in the Scopus database. On the other hand, Web of Science stands out for publishing $78 \%$ of articles, followed by the "Conference Papers" with $19 \%$.
Table 5 Types of published documents (1987-2016)

\begin{tabular}{lclc}
\hline \multicolumn{1}{c}{ Scopus } & \multicolumn{3}{c}{ Web of Science } \\
\hline \multicolumn{1}{c}{ Document Type } & $\%$ & \multicolumn{1}{c}{ Document Type } & $\%$ \\
\hline Articles & $74.00 \%$ & Articles & $78.00 \%$ \\
Conference Papers & $13.0 \%$ & Conference Papers & $19.00 \%$ \\
Book Chapters & $8.00 \%$ & Reviews & $1.0 \%$ \\
Reviews & $3.00 \%$ & Book Reviews & $1.00 \%$ \\
Book & $1.00 \%$ & Editorial Material & $1.00 \%$ \\
Editorials & $0.4 \%$ & & \\
Notes & $0.2 \%$ & & $100 \%$ \\
Short Surveys & $0.2 \%$ & & \\
Articles in Press & $0.1 \%$ & & \\
\hline
\end{tabular}


Another information for the paper's objective refers to the journals which were used the most by the authors to publish their works (Table 6). We found that, in the Scopus database, during the researched period, the most used scientific journal was Espacios with a total of 320 publications, followed by the Journal of Technology Management and
Innovation with 202 publications and the journal Gestão e Produção with 72 publications. In contrast, in the Web of Science database, the journal with the highest publishing numbers are Revista INTEC with 40 publications, Research Policy with 37 and RAE- Revista de Administração de Empresas with 30.

Table 6 Journals with the highest numbers of publications on innovation (1987-2016)

\begin{tabular}{|c|c|c|c|c|}
\hline \multirow[b]{2}{*}{ Rank } & \multicolumn{2}{|l|}{ Scopus } & \multicolumn{2}{|l|}{ Web of Science } \\
\hline & Journal & Number of publications & Journal & Number of publications \\
\hline 1 & Espacios & 320 & Revista INTEC & 40 \\
\hline 2 & $\begin{array}{l}\text { Journal of Technology Management and } \\
\text { Innovation }\end{array}$ & 202 & Research Policy & 37 \\
\hline 3 & Gestão e Produção & 72 & RAE-Revista de Administração de Empresas & 30 \\
\hline 4 & Research Policy & 35 & Technological Forecasting and Social Change & 29 \\
\hline 5 & Journal of Cleaner Production & 32 & Revista Brasileira de Inovação & 28 \\
\hline 6 & $\begin{array}{c}\text { Technological Forecasting and Social } \\
\text { Change }\end{array}$ & 30 & Journal of Business Research & 27 \\
\hline 7 & RAE-Revista de Administração de Empresas & 29 & Science and Public Policy & 25 \\
\hline 8 & Latin America Business Review & 24 & Technovation & 24 \\
\hline 9 & Revista de Economia e Sociologia Rural & 23 & $\begin{array}{c}\text { Innovar Revista de Ciencias Administrativas } \\
\text { y Sociales }\end{array}$ & 20 \\
\hline 10 & Desarrollo Economico & 22 & Revista Brasileira de Gestão e Negócios & 19 \\
\hline 11 & Innovar & 22 & Revista de Gestão e Tecnologia & 19 \\
\hline 12 & Journal of Business Research & 22 & Revista Latinoamericana de Administración & 18 \\
\hline 13 & Technovation & 20 & Trimestre Econômico & 16 \\
\hline 14 & Brazilian Administration Review & 18 & World Development & 15 \\
\hline 15 & $\begin{array}{c}\text { International Journal of Innovation and } \\
\text { Learning }\end{array}$ & 18 & $\begin{array}{l}\text { International Journal of Technology Mana- } \\
\text { gement }\end{array}$ & 15 \\
\hline 16 & Revista de Economia Política & 18 & Revista Gestión de las Personas y Tecnologia & 13 \\
\hline 17 & Agroalimentaria & 17 & Revista de Ciencias Sociales & 13 \\
\hline 18 & Mundo Agrário & 17 & International Journal of Innovation & 12 \\
\hline 19 & Nova Economia & 17 & Emerging Markets, Finance and Trade & 11 \\
\hline 20 & Trimestre Econômico & 17 & Service Industries Journal & 10 \\
\hline
\end{tabular}

\section{Most productive authors}

Regarding the authors that publish the most (Table 7), we did not find any unanimity between the databases searched. In the Scopus database, the first three positions are occupied by Kruglianskas, I. (Brazil), Gomes, C.M. (Brazil), e Sbragia, R (Brazil) each one with 16, 15, and 14 publications respectively. In the Web of Science database, the authors Guevara, A.J.D (Brazil), Figueiredo, P.N. (Brazil) e Bogliacino, F. (Colombia) emerge, each one with 10, 10 and nine publications respectively.
The authors with the highest citation volume identified in the Scopus database are Sutz, J., Cimoli, M., Bogliacino, F. and Figueiredo, P. N., respectively accounting for $185,91,90$ and 80 citations each. On the other hand, in the Web of Science database, the most cited authors are Vassolo, R. S., Figueiredo, P.N., Boehm, D.M. e Dutrenit, G, each one with $215,133,85$ and 76 citations respectively. Such data show that there are authors with a large number of publications that, however, do not present a high citation volume, which is the case of Dandolini, G. A. in the Scopus database, and Guevara, A.J.D. and Correa, R.M. in the Web of Science database. 
Table 7 Authors with the highest number of publications on innovation (1987-2016)

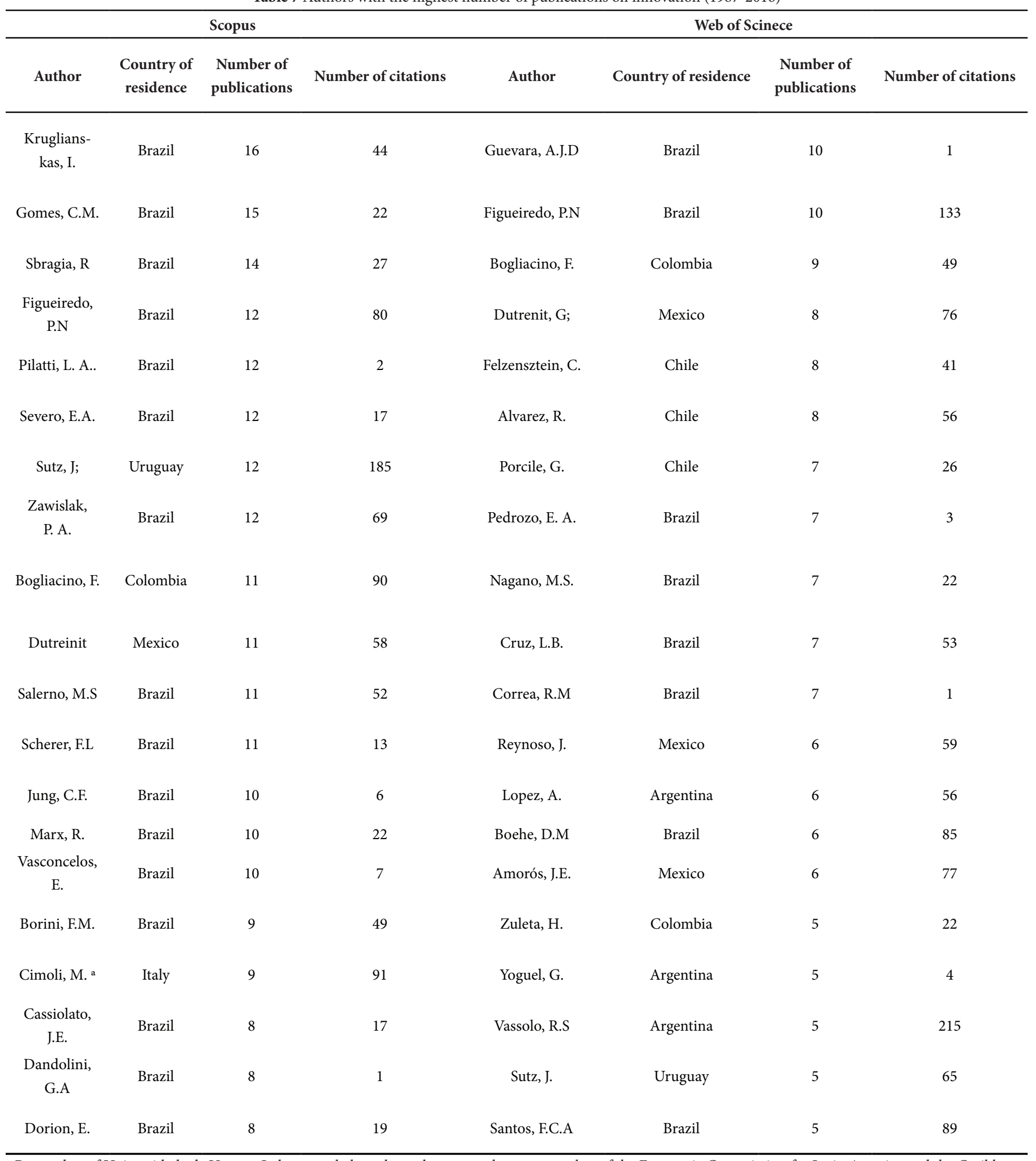

a Researcher of Universidade de Veneza, Italy, nevertheless, the author researches as a member of the Economic Commission for Latin America and the Caribbean. 
Another fact worth mentioning regarding the region's highest publishing authors is the non-appearance of some relevant Latin American authors that research on the theme. Authors such as Jorge Katz, Carlota Perez, Jorge Sábato and Francisco Sagasti do not figure in the ranking from the databases. Four reasons may explain this phenomenon: the publishing vehicle type chosen by these authors, the research themes to which these authors have dedicated themselves in the last 30 years, the emergence of new researchers in this area and the author's affiliation, who may be associated to universities that are outside Latin America. It is also relevant to note that, in case the authors focus on using "Books" as the means to publish their works, they will be encompassed in the $1 \%$ scope of the Latin American publications about innovation, as observed in Table 5.

\section{Most used languages}

Finally, we also surveyed the most used languages in the publications. The majority, in both databases, was published in English, followed by Portuguese and Spanish, respectively. One possible explanation for these results may be that the vast majority of the relevant journals on the theme are internationalized, that is, they adopt English as the publishing language and, because of that, they receive greater attention from Latin American researchers. Portuguese is the second most used language for publishing in the region (Table 8).

Table 8 Language of the publications (1987-2017)

\begin{tabular}{cccc}
\hline Scopus & \multicolumn{2}{c}{ Web of Science } \\
\hline Language & $\%$ & Language & $\%$ \\
\hline English & $71 \%$ & English & $76 \%$ \\
Portuguese & $17 \%$ & Portuguese & $12 \%$ \\
Spanish & $12 \%$ & Spanish & $12 \%$ \\
\hline & $100 \%$ & & $100 \%$ \\
\hline
\end{tabular}

Thus, in the face of all this data gathered through the bibliometric method applied in the Scopus and Web of Science databases, it is possible to conclude how studies on innovation are being developed by Latin American authors living in the region. Given, the following concluding section presents the conclusions drawn from the data gathered in this paper, as well as the limitations that can serve as suggestions for future studies.

\section{Conclusions}

By reaching the article's objective of analyzing a quantitative panorama (bibliometric analysis) about the studies that comprise the innovation theme in the Latin American context, it was possible to perceive that Latin America is a vital region for the development of this theme. Latin America is responsible for $8 \%$ of the world GDP, comprised $8.5 \%$ of the world population and maintained an average growth rate of $4.9 \%$ during the period between 2002 and 2012, which is above the world average (International Monetary Fund, 2013). Furthermore, the world economic context shows that from the 1990 decade to 2014, Latin America characterized as a region with positive economic performance, macroeconomic stability, and growing visibility in the media (Brenes et al., 2016). Despite the favorable scenario during the period, the region only marginally contributes to the innovation activities worldwide (Ketelhon \& Ogliastri, 2013). Therefore, obtaining information regarding the panorama of the different research areas is a necessary task.

This study aimed to provide an overview of the innovation studies performed by Latin American authors. Thus, this analysis provides a guide for newcomers on the innovation field by presenting information on the journals to refer to and the most prominent authors in the Latin American context. The results indicate that despite the region's economic and populational representativeness, until 2006, there were few innovation studies. The number of publications only grew after 2006, placing Brazil, Mexico, Colombia, and Chile as the region exponents. Although this growth was representative for the region, it represented very little when compared to the world's publication, that is, the Latin American region produces, on average, 2.75\% (in both databases) of the world's publications on innovation. According to Crespi and Dutrénit (2014), this can be justified by the low GDP ratios invested in R\&D. Sanz and Jones (2013) highlight that Latin-American companies invest $0.5 \%$ of their gross revenue on research and development, in comparison to more developed regions which invest $2 \%$. In this scenario, Mexico invests $0.47 \%$ of the GDP in R\&D, Argentina invests $0.40 \%$, Uruguay $0.19 \%$, while the United States, one of the countries with the highest number of publications, according to data from De Negri and Squeff (2014), invests $2.8 \%$ of its GDP on R\&D. Besides, another fact that corroborates for the low R\&D investment rates is the number of patents derived from these investments, and this is clear in the comparison between the leading regions in the number of patents and Latin America. While Asia, North America, and Europe account for 49.7\%, $26.1 \%$, and $18.6 \%$ of the world patent applications, Latin America only accounts for $3.0 \%$ of the applications.

Regarding the comparison of Latin American countries with the world leading publishing countries, the United States ranks first, followed by the United Kingdom and China. Nonetheless, the only Latin American country to figure among the top fifteen publishing countries is Brazil, which occupies the fifteenth position in the Scopus database, ahead of countries like Sweden and Denmark. Such a phenomenon is noted when we assess the difference in the number of publications of Latin American countries. The difference between Brazil and the rest of the block is significant, which gives prominence to Brazilian researchers, as well as Brazilian universities. However, despite the majority regarding publications, Brazil is still behind such countries as Chile and Trinidade and Tobago in C/P and P/Pop indices. Nevertheless, in spite of the higher $\mathrm{C} / \mathrm{P}$ and $\mathrm{P} / \mathrm{Pop}$ scores when compared to Brazil, the quantity of publications in absolute terms of Chile and Trinidadand Tobago are still inferior to the Brazilian numbers - together, both countries have less than half Brazilian publications - which highlights the Brazilian protagonism in the region. A reflection of that resides on Brazilian institutions ranking first in publication numbers. Another fact that can justify that, according to Crespi and Dutrénit (2014), is the investment in R\&D which corresponds to $1.16 \%$ of the Brazilian GDP, higher than the rest of the Latin American countries. 
Moreover, we also found that Latin American countries still fall short on publications about innovation. This scenario may be an explanatory factor as to why the region does not figure among the developed regions of the world since innovation is an explanatory variable to verify performance differences between firms, regions, and countries (Zawislak et al., 2017). Nevertheless, this scenario of relative delay presented by Latin America in comparison to the rest of the world seems to be slowly fading. This decrease in the delay is because the world, for a long time, did not present significant volumes of publications either and in a given period the volume of publications escalated (Fagerberg \& Verspagen, 2009). In such logic, we observe that the trajectory of innovation studies in Latin America is following the global tendency, but with a certain delay. Thus, the Latin American region still presents a marginal contribution to the bibliographic production about innovation in the world (Ketelhöhn \& Ogliastri, 2013).

Finally, the elaboration of this paper is justified on the incipient existence of bibliometric studies focused on innovation that encompass the region which, in turn, leads to the inexistence of reliable indicators to support decision-making regarding public policies for the development of the area. As mentioned on the introduction, bibliometric papers address innovation in their most diverse aspects, from innovation in general to specific areas of innovation, such as open innovation and innovation in services (Fagerberg \& Verspagens, 2009; Fagerberg et al., 2012; Zhu \& Guan, 2013; Sun \& Grimes, 2016; Cancino, Merigó \& Coronado, 2017), nevertheless, none of these papers has focused on Latin America. In the region, under the optics of the bibliometric method, a few studies though, stand out by addressing different scopes, such as the paper of Ronda-Pupo (2016), who mapped the Latin American knowledge on management, the work of De Moya-Anegón and Herrero-Solana (1999), who compared the bibliometric and scientific indicators of the region, and that of CollazoReyes (2014), whose research theme addressed the growth of Latin American journals.

Additionally, this article provides important subsidies for the elaboration of public policies. First, we identified that the volume of studies on innovation has grown in the last decades, which provides evidence for the existence of a critical body of researchers which can further develop research on the field. Nevertheless, not all countries in the region present a body of scholars researching the area and, based on that, we suggest countries with a reduced amount of research on the theme to increase investments on the innovation field. Second, our findings show that Latin-American researchers have collaborated with leading countries on this knowledge field. Therefore, we suggest researchers to advance this collaboration. Third, public policies must focus on increasing the quality and the impact of the research from the region. This is the case of Brazil, where the challenge resides on the impact of research rather than on the quantity. On the other hand, for the rest of the Latin-American countries, the challenge is to increase the quantity while maintaining the impact of the research conducted. Finally, we recommend a set of informative and formative public policies to develop an innovation culture in the region. The development of an innovation culture must be the sum of conjoint efforts from economic agents, practitioners, workers, and public agents. Developing such an innovation culture is a long-term task which will result in a driver to lead the economic growth in Latin America in the next decades.

Despite reaching its objectives, this paper has limitations. One limitation resides on a parcel of the Latin American authors that may not have been counted. Alternatively, these authors may be affiliated to institutions that are outside the study's coverage field.

\section{References}

Bjork, S., Offer, A., \& Söderberg, G. (2014). Time series citation data: The Nobel Prize in economics. Scientometrics, 98(1), 185-196. https://doi.org/10.1007/s11192-013-0989-5

Bonilla, C. A., Merigó, J. M., \& Torres-Abad, C. (2015). Economics in Latin America: a bibliometric analysis. Scientometrics, 105(2), 12391252. https://doi.org/10.1007/s11192-015-1747-7

Boyack, K. W., Wylie, B. N., \& Davidson, G. S. (2002). Domain visualization using vxinsight for science and technology management. Journal of the American Society for Information Science and Technology, 53(9), 764-774. https://doi.org/10.1002/asi.10066

Brenes, E. R., Camacho, A. R., Ciravegna, L., \& Pichardo, C. A. (2016). Strategy and innovation in emerging economies after the end of the commodity boom-Insights from Latin America. Journal of Business Research, 69(10), 4363-4367. https://doi.org/10.1016/j.jbusres.2016.03.059

Cancino, C., Merigó, M. \& Coronado, F. (2017). A bibliometric analysis of leading universities in innovation research. Journal of Innovation \& Knowledge, 2(3), 106-124. https://doi.org/10.1016/j.jik.2017.03.006

Christensen, C. M. (1997). The innovator's dilemma: when new technologies cause great firms to fail. Cambridge: Harvard Business Review Press.

Collazo-Reyes, F. (2014). Growth of the number of indexed journals of Latin America and the Caribbean: the effect on the impact of each country. Scientometrics, 98(1), 197-209. https://doi.org/10.1007/ s11192-013-1036-2

Crespi G., \& Dutrénit G. (2014). Science, Technology and Innovation Policies for Development: The Latin American Experience. Berlin: Springer. https://doi.org/10.1007/978-3-319-04108-7_1

De Moya-Anegón, F., \& Herrero-Solana, V. (1999). Science in America Latina: a comparison of bibliometric and scientific-technical indicators. Scientometrics, 46(2), 299-320. https://doi.org/10.1007/ bf02464780

Dosi, G. (1982). Technological paradigms and technological trajectories. Research Policy, 11(3), 147-162. https://doi.org/10.1016/00487333(82)90016-6

Fagerberg, J., \& Verspagen, B. (2009). Innovation studies - The emerging structure of a new scientific field. Research Policy, 38(2), 218 233. https://doi.org/10.1016/j.respol.2008.12.006 
Fagerberg, J., Fosaas, M., Bell, M., \& Martin, B. R. (2011). Christopher Freeman: social science entrepreneur. Research Policy, 40(7), 897-916. https://doi.org/10.1016/j.respol.2011.06.011

Fagerberg, J., Fosaas, M., \& Sapprasert, K. (2012). Innovation: Exploring the knowledge base. Research Policy, 41(7), 1132-1153. https:// doi.org/10.1016/j.respol.2012.03.008

Freeman, C. (1974). The Economics of Industrial Innovation. London: Penguin Books Ltda.

Godin, B. (2014). Innovation Studies: Staking the Claim for a New Disciplinary Tribe. Minerva, 52(4), 489-495. https://doi.org/10.1007/ s11024-014-9262-1

International Monetary Fund (2013). World Economic Outlook 2013. Washington, D.C. https://doi.org/10.5089/9781484372265.081

Katz, J. M. (1984). Domestic technological innovations and dynamic comparative advantage: further reflections on a comparative casestudy program. Journal of Development Economics, 16(1-2), 13-37. https://doi.org/10.1016/0304-3878(84)90100-7

Ketelhöhn, N. \& Ogliastri, E. (2013). Introduction: innovation in Latin America. Academia. Revista Latinoamericana de Administración, 26(1), 12-32. https://doi.org/10.1108/arla-05-2013-0037

Lazzarotti, F., Samir Dalfovo, M., \& Emil Hoffmann, V. (2011). A bibliometric study of innovation based on Schumpeter. Journal of technology management \& innovation, 6(4), 121-135. https://doi. org/10.4067/s0718-27242011000400010

Lundvall, B.A. (1992). National Systems of Innovation: Towards a Theory of Innovation and Interactive Learning, London: Pinter.

Martin, B. R. (2016). Twenty challenges for innovation studies. Science and Public Policy, 43(3), 432-450. https://doi.org/10.1093/scipol/scv077

Negri, F. \& Squeff, F. (2014). Investimentos em P\&D do governo norte-americano: evolução e principais características. In Boletim Radar 36: tecnologia, produção e comércio exterior, Instituto de Pesquisa Econômica Aplicada. Brasilia: Ipea.

Nelson, R.R., \& Winter, S. (1982). An Evolutionary Theory of Economic Change. Boston, MA: Harvard University Press.

OECD/ECLAF/CAF. (2017). Latin American Economic Outlook 2017: Youth, Skills and Entrepreneurship. OECD Publishing: Paris. http:// dx.doi.org/10.1787/leo-2017-en

Olavarrieta, S., \& Villena, M. G. (2014). Innovation and business research in Latin America: An overview. Journal of Business Research, 67(4), 489-497. https://doi.org/10.1016/j.jbusres.2013.11.005

Pavitt, K. (1984). Sectoral patterns of technical change: Towards a taxonomy and a theory. Research Policy, 13(6), 343-373. https://doi. org/10.1016/0048-7333(84)90018-0
Penrose, E.T. (1959), The Theory of the Growth of the Firm, Oxford: Basil Blackwell.

Pérez, C. (1986). Las nuevas tecnologías: una visión de conjunto. Estudios internacionales, 19(76), 420-459. https://doi.org/10.5354/07193769.1986 .15690

Ronda-Pupo, G. A. (2016). Knowledge map of Latin American research on management: Trends and future advancement. Social Science Information, 55(1), 3-27. https://doi.org/10.1177/0539018415610225

Rosenberg, N. (1976). Perspectives on technology. Cambridge: Cambridge University Press.

Sábato, J (1971). Ciencia, tecnología, desarrollo y dependencia. Editorial Mensaje: Tucumán.

Sagasti, F. R. (1973). Underdevelopment, science and technology: the point of view of the underdeveloped countries. Science Studies, 3(1), 47-59. https://doi.org/10.1177/030631277300300104

Sanz, L., \& Jones, V. (2013). Advances in business research in Latin American studies. Journal of Business Research, 66(3), 397-400. https://doi.org/10.1016/j.jbusres.2012.04.005

Schumpeter, J.A. (1911). The Theory of Economic Development, Cambridge, MA: Harvard University Press.

Schumpeter, J. A. (1942). Socialism, capitalism and democracy. New York: Harper and Brothers.

Solow, R. M. (1957). Technical change and the aggregate production function. The Review of Economics and Statistics, 39(3), 312-320. https://doi.org/10.2307/1926047

Sun, Y., \& Grimes, S. (2016). The emerging dynamic structure of national innovation studies: a bibliometric analysis. Scientometrics, 106(1), 17-40. https://doi.org/10.1007/s11192-015-1778-0

Teece, D. J. (1986). Profiting from Technological Innovation: Implications for integration, collaboration, licensing and public policy. Research policy, 15(6), 285-305. https://doi.org/10.1016/00487333(86)90027-2

The World Bank (2018). World Development Indicators. Retrieved February 15, 2015, from http://databank.worldbank.org/data/reports. asp $x$ ? source $=2 \&$ series $=$ SP.POP.TOTL\&country=\#.

Zawislak, P., Tello-Gamarra, J., Fracasso, E. \& Castellanos, O. (2017). Innovation beyond technology: perspectives from Latin America. Academia. Revista Latinoamericana de Administración, 30 (4), 420 428. https://doi.org/10.1108/arla-07-2017-0221

Zhu, W., \& Guan, J. (2013). A bibliometric study of service innovation research: Based on complex network analysis. Scientometrics, 94(3), 1195-1216. https://doi.org/10.1007/s11192-012-0888-1 
